\title{
Physico-chemical characteristics of carcass and Longissimus dorsi quality in three white crossbreed pigs: comparison to Iberian quality
}

\author{
Manrique, M. ${ }^{1}$; Lostao, Y. ${ }^{2}$; Antolín, G. ${ }^{3}$; Gutierrez, A. ${ }^{4}$ \\ ${ }^{1}$ Fundación CARTIF. Parque Tecnológico Boecillo Parcela 205, 47151 Valladolid. Spain. mirman@cartif.es \\ ${ }^{2}$ Consultora Veterinaria. Zaragoza, Spain. \\ ${ }^{3}$ ETSII. Universidad Valladolid. Paseo Cauce s/n, 47011 Valladolid, Spain. \\ ${ }^{4}$ Acompor. Pol Industrial Los Arenales s/n, 40213 Segovia, Spain
}

\begin{abstract}
:
The aim of this research is to achieve fresh meat and carcass quality in white crossbreed pigs (LPP, LP, LPY) comparable with Iberian characteristics, measurable mainly by intramuscular fatty acids in $L$. dorsi and subcutaneous fat profile in carcass. Muscle meat showed IMF $>3 \%$, relevant for fresh sensorial quality, LP showed higher IMF $(p<0,001), a^{*}(p<0,01)$ and lower moisture $(p<0,05)$. Crossing breed had no effect on major parameters but fattening diet affected IMF and subcutaneous fat profiles. Moisture, IMF and protein content in LPP and LPY were in agreement with results obtained in studied Iberians for fresh while LP agreed with those reported for dry cured products. In IMF and subcutaneous fat, the positive effect of feeding diet, increasing oleic and lowering linoleic content significatively $(p<0,001)$ revealed similar results to Iberian studies.
\end{abstract}

Keywords: white pig, meat quality, intramuscular fat, subcutaneous fat.

\section{Background and objective:}

Traditionally, in Spain, Iberian herds have been primarily manufactured for dry cured products, since they were highly appreciated for its sensorial quality and considerably priced. Lately, Iberian pig meat has been marketed as a solid quality alternative to lean pig meat for fresh consumption. Several studies have analyzed Iberian and white pig meat and carcass characteristics (Hernandez et al., 1997; Xerra et al., 1998; Estevez et al., 2003; Muriel et al., 2004). Likewise, consumers are aware of the influence of meat lipids intake on health. Thus, the purpose of this research is to evaluate physico-chemically Longissimus dorsi muscle and characterize the fatty acid profile in carcass adipose tissue from three white crossbreed pigs in order to compare fresh meat and carcass quality with Iberian studies.

\section{Methods:}

Animals and diets: 99 pigs from three white crossbreeds -Large WhitexPietrainxPietrain (LPP), Large WhitexPietrain (LP) and Large WhitexPietrainxYork (LPY) (Acompor farm)allotted to two different intensive feeding diets: same protein content but different source soya or beer yeast-, different sugar and fat content but AGI/AGS constant. Sampling: L. dorsi from left half carcass was removed as well as adipose tissue from the tail insertion area in the coxal region. Analytical methodology: In $L$. dorsi, meat colour by $\mathrm{L}^{*}, \mathrm{a}^{*}, \mathrm{~b}^{*}$ values with a CM300 Minolta chromameter, moisture, protein content and IMF by Infratec 1265 Meat Analyzer were quantified. Intramuscular total lipids were extracted as described by Bligh and Dyer (1959). In carcass, subcutaneous adipose tissue was processed as described by ASICI. Fatty acid methyl esters prepared and analysed by gas chromatography. Statistical analysis: The effect of crossing breed was evaluated by one way ANOVA with carcass weight as covariable. When significant, means were compared by Tukey HSD at level $p<0,05$. The effect of diet was assessed by t-student for independent samples. Statistica v 5.5.

\section{Discussion and conclusions:}

IMF $>3 \%$ though LPP and LPY better fulfil consumer preferences. Moisture, IMF and protein content in LPP and LPY are in agreement with Iberian studies $(72.8 \% / 73.37 \% / 73.65 \%)$ 
moisture, (3.91\%/3.17\%/2.51\%) IMF, $(22.6 \%)$ protein. LP shows higher IMF, suitable for dry cured products. $\mathrm{L}^{*}$ is higher (paler) and $\mathrm{a}^{*}$ is lower than expected and comparing to (54.1/43.40-46.55) (7.47/9.48-11.40) in Iberians and similar to (55.9/56.77) or still low (6.57/7.24) in white breeds. So redness of meat should be enhanced and controlled. Fattening diet affects IMF and subcutaneous fat profiles, specially increasing oleic $-\Sigma M U F A-$ and lowering linoleic acid - $\Sigma$ PUFA- levels. In view of the results obtained, feeding diet B enhances fatty acid profile, closer to Iberian meat, and also become a better market option than lean white pigs.

\begin{tabular}{|l|c|c|c|c|}
\hline \multicolumn{7}{|l|}{ Table 1. Moisture, IMF, protein content and CIE L* $\mathbf{~}^{*}$ in $\mathbf{L . d o r s i}$} \\
\hline \multicolumn{1}{|c|}{ Parameter } & LPP & LP & LPY & Statistical sig. \\
\hline Moisture & $74,11 \mathrm{a} \pm 1,29$ & $72,63 \mathrm{~b} \pm 1,41$ & $73,24 \mathrm{ab} \pm 1,47$ & $*$ \\
\hline IMF (g/100 g muscle) & $3,00 \mathrm{a} \pm 1,06$ & $5,10 \mathrm{~b} \pm 1,66$ & $3,96 \mathrm{a} \pm 1,64$ & $* * * / *$ \\
\hline Protein $(\mathrm{g} / 100 \mathrm{~g}$ muscle) & $22,21 \pm 0,74$ & $21,64 \pm 0,75$ & $22,08 \pm 0,74$ & $\mathrm{~ns}$ \\
\hline $\mathrm{L}^{*}$ & $54,88 \mathrm{a} \pm 4,49$ & $55,23 \mathrm{a} \pm 3,13$ & $57,58 \mathrm{~b} \pm 2,96$ & $*$ \\
\hline $\mathrm{a}^{*}$ & $2,87 \mathrm{a} \pm 1,06$ & $3,89 \mathrm{~b} \pm 1,00$ & $3,30 \mathrm{ab} \pm 1,25$ & $* *$ \\
\hline
\end{tabular}

Means with different letters differed significantly. ns: not significant. ${ }^{*} \mathrm{P}<0,05 ; * * \mathrm{P}<0,01 ; * * * \mathrm{P}<0,001 ;$

\begin{tabular}{|c|c|c|c|c|c|c|c|}
\hline Fatty a. & Feed A & Feed B & Signif & Fatty a. & Feed A & Feed B & Signif \\
\hline C16:0 & $23,68 \mathrm{a} \pm 0,71$ & $24,87 b \pm 0,44$ & $*$ & C18.1 & $41,94 a \pm 0,84$ & $46,78 b \pm 0,44$ & $* * *$ \\
\hline C18:0 & $13,34 \pm 0,88$ & $13,47 \pm 0,44$ & ns & $\Sigma$ MUFA & $46,05 \mathrm{a} \pm 1,09$ & $51,47 b \pm 0,66$ & $* * *$ \\
\hline C20:0 & $0,19 \pm 0,04$ & $0,16 \pm 0,02$ & ns & C18:2 & $11,98 \mathrm{a} \pm 0,61$ & $5,43 b \pm 0,90$ & $* * *$ \\
\hline \multirow[t]{2}{*}{$\Sigma$ SFA } & $38,81 \mathrm{a} \pm 0,99$ & $40,09 b \pm 0,61$ & $*$ & C18:3 & $0,56 \mathrm{a} \pm 0,19$ & $0,16 b \pm 0,03$ & $*$ \\
\hline & & & & $\Sigma$ PUFA & $14,54 \mathrm{a} \pm 1,24$ & $7,61 b \pm 0,75$ & $* * *$ \\
\hline
\end{tabular}

Means with different letters differed significantly. ns: not significant. ${ }^{*} \mathrm{P}<0,05 ; * * \mathrm{P}<0,01 ; * * * \mathrm{P}<0,001$;

\begin{tabular}{|l|c|c|c|}
\hline \multicolumn{4}{|l|}{ Table 3. Diet effect on carcass backfat fatty acid composition (g/100 g FAMEs). } \\
\hline Fatty acid & Feed $\mathrm{A}$ & Feed B & Statistical sig \\
\hline $\mathrm{C} 16: 0$ & $23,08 \mathrm{a} \pm 0,07$ & $24,36 \mathrm{~b} \pm 0,41$ & $* *$ \\
\hline $\mathrm{C} 18: 0$ & $10,92 \mathrm{a} \pm 0,60$ & $11,49 \mathrm{~b} \pm 0,42$ & $*$ \\
\hline $\mathrm{C} 18.1$ & $44,55 \mathrm{a} \pm 0,34$ & $49,16 \mathrm{~b} \pm 0,91$ & $* *$ \\
\hline $\mathrm{C} 18.2$ & $13,06 \mathrm{a} \pm 0,12$ & $6,96 \mathrm{~b} \pm 0,59$ & $* *$ \\
\hline
\end{tabular}

Means with different letters differed significantly. ns: not significant. $* \mathrm{P}<0,05 ; * * \mathrm{P}<0,01 ; * * * \mathrm{P}<0,001$;

\section{Acknowledgements:}

The authors wish to thank CDTI for its financial support (TAM/2001-0105) and Estación Tecnológica de la Carne de Guijuelo for their facilities and technical assistance.

\section{References:}

ASICI (Iberian Pigs Interprofesional Association). www.iberico.com.

Bligh, E.G; Dyer, E.J. (1959). A rapid method of total lipid extraction and purification in Canadian Journal of Biochemistry and Physiology, 37, pp 911-917.

Estévez, M; Morcuende, D; Cava-López, R. (2003). Physico-chemical characteristics of M Longissimus dorsi from three lines of free-range reared Iberian pigs slaughtered at $90 \mathrm{~kg}$ live-weight and commercial pigs: a comparative study en Meat Science 64, pp 499-506.

Hernández, P; Navarro, J.L; Toldrá, F. (1998). Lipid composition and lipolytic enzyme activities in porcine skeletal muscles with different oxidative pattern in Meat Science vol 49, 1, pp 1-10.

Muriel, E; Ruíz, J; Ventanas, J; Petrón, M.J; Antequera, T. (2004). Meat quality characteristics in different lines of Iberian pigs en Meat Science 67, pp 299-307.

Serra, X; Gil, F; Pérez-Enciso, M; Oliver, M.A; Vázquez, J.M; Gispert, M; Díaz, I; Moreno, F; Latorre, R; Noguera, J.L. (1998). A comparison of carcass, meat quality and histochemical characteristics of Iberian (Guadyerbas line) and Landrance pigs in Livestock Production Science 56, pp 215-223. 